\title{
Effect of the Presence of Nonionic Surfactant Brij35 on the Mobility of Metribuzin in Soil
}

\section{Eman M. ElSayed * and Shiv O. Prasher}

Department of Bioresource Engineering, McGill University, Ste. Anne de Bellevue, Quebec H9X 3V9, Canada; E-Mail: shiv.prasher@mcgill.ca

* Author to whom correspondence should be addressed; E-Mail: eman.elsayed@mail.mcgill.ca; Tel.: +1-514-463-7799.

Received: 31 December 2012; in revised form: 22 March 2013 / Accepted: 25 March 2013 / Published: 24 April 2013

\begin{abstract}
Given the water scarcity becoming endemic to a large portion of the globe, arid region irrigation has resorted to the use of treated, partially treated, or even untreated wastewaters. Such waters contain a number of pollutants, including surfactants. Applied to agricultural lands, these surfactants could affect the fate and transport of other chemicals in the soil, particularly pesticides. A field lysimeter study was undertaken to investigate the effect of nonionic surfactant, Brij35, on the in-soil fate and transport of a commonly used herbicide, metribuzin [4-amino-6-tert-butyl-3-(methylthio)-1,2,4-triazin-5(4H)-one]. Nine PVC lysimeters, $1.0 \mathrm{~m}$ long $\times 0.45 \mathrm{~m}$ diameter, were packed with a sandy soil to a bulk density of $1.35 \mathrm{mg} \mathrm{m}^{-3}$. Antibiotic-free cattle manure was applied $\left(10 \mathrm{mg} \mathrm{ha}^{-1}\right)$ at the surface of the lysimeters. Metribuzin was then applied to the soil surface of all lysimeters at a rate of $1.00 \mathrm{~kg}$ a.i. ha ${ }^{-1}$. Each of three aqueous Brij35 solutions, $0,0.5$ and $5 \mathrm{mg} \mathrm{L}^{-1}$ (i.e., "good", "poor" and "very poor" quality irrigation water) were each applied to the lysimeters in triplicate. Analysis for metribuzin residues in samples of both soil and leachate, collected over a 90-day period, showed the surfactant Brij35 to have increased the mobility of metribuzin in soil, indicating that continued use of poor quality water could influence pesticide transport in agricultural soils, and increase the risk of groundwater contamination.
\end{abstract}

Keywords: nonionic surfactant; Brij35; herbicide; mobility; wastewater; sandy soil 


\section{Introduction}

Water is a very complex and dynamic resource and although the estimated amount of the available water on the planet is 140 billion $\mathrm{km}^{3}$, only $3 \%$ is fresh water [1]. Due to the distribution of fresh water resources around the globe, less than $1 \%$ of these resources are available for human use. This, in turn, leads to water shortage problems in many regions of the world, particularly developing countries. Water scarcity combined with poverty is forcing the reuse of untreated or partially-treated wastewater for irrigation in order to cope with the high food demands of growing populations [2]. Consequently, the risk of bacterial infections, roundworms and diarrheal diseases are much greater [3]. A recent survey revealed that the 46 countries, representing $75 \%$ of the world's irrigated land, use polluted water for irrigation [4]. Globally, an estimated 20 million ha of land are irrigated with wastewater, and this area is expected to markedly increase in the next few years [5].

Wastewater, originating from the discharge of municipal and industrial effluents, contains a number of inorganic and organic substances. Among organic contaminants of wastewater and sludge, surfactants are often detected at the highest concentrations [6-8]. Non-ionic surfactants concentrations ranging from $10^{2}$ to $10^{3} \mathrm{mg} \mathrm{L}^{-1}$ have been detected in wastewater [9]. Non-ionic surfactants such as alcohol ethoxylates (AEs), alkylphenol ethoxylates (APE) are used extensively as leather degreasing agents and in other textile industry applications. Consequently, non-ionic surfactants have been identified as major contaminants in untreated wastewater from such industries [10,11]. Owing a non-dissociable hydrophilic group (e.g., alcohol, phenol, ether, ester, or amide), non-ionic surfactants do not ionize in water. Although in the wastewater treatment plants, APEs degrade into metabolites such as nonylphenol ethoxylates (NPEs), treatment plants are not adequately efficient to remove the metabolites such as environmentally damaging nonylphenols (NPs) [12,13]. Consequently, nonylphenols (NPs) were detected at high concentrations ranging from 1.8 to $25 \mathrm{~g} \mathrm{~L}^{-1}$ in two rivers in Switzerland [14]. Further, studies showed that the continuous use of household products containing AEs, contributes to NPE and NP loads in urban sewer waters [13,15].

Certain AEs are now used as an alternative to alkyl polyphenol ethoxylates (APEOs), as they are safer as result of their rapid breakdown to less toxic, less persistent and less estrogenic compounds. Generally, the presence of nonionic surfactants in irrigation water leads to two major concerns: (1) The degradation products of non-ionic surfactants such as nonylohenol ethoxylates (NPEO) and NP act as estrogen mimicking compounds, leading to symptoms like change in sex ratio, decrease in fish population and malformations in some aquatic animals [16]. In terms of the estrogenic effects, a study in US raised a great concern of potable water contamination by NPs which have been detected in some wells. The authors reported that the source of these compounds is the continuous infiltration disposal of wastewater treatment plant effluents [17]. (2) Non-ionic surfactants in the irrigation water may have an impact on the mobility of chemicals in soil and cause contamination of groundwater [18-21]. Katagi (2008) [22] reported that the downward movement of pesticides in soil was enhanced by the presence of high non-ionic surfactant concentrations in leaching water. However, the effect may depend on the surfactant concentration. Similarly, Tao et al. (2006) [23] indicated that, at low concentrations $0-20 \mathrm{mg} \mathrm{L}^{-1}$, surfactants have the potential to decrease sorption and thus mobilize herbicides such as atrazine. For example, at low concentrations $\left(0.04 \mathrm{~g} \mathrm{~kg}^{-1}\right)$, non-ionic surfactants decreased the mobility of the herbicide metolachlor in soil; however, at high concentrations $\left(5-50 \mathrm{~g} \mathrm{~kg}^{-1}\right)$, 
the mobility increased [24]. A lysimeter study revealed that at a low concentration $\left(12 \mathrm{mg} \mathrm{L}^{-1}\right)$, NP had no effect on the mobility of atrazine, metolachlor and metribuzin in sandy soil [25].

Pesticide contamination of water bodies has generated a great deal of concern. Generally, it results from diffuse (non-point) sources such as runoff and leaching from agricultural lands. Triazinones herbicides, such as metribuzin (4-amino-6-tert-butyl-4,5-dihydro-3-methyltio-1,2,4-triazin-5-one), are used worldwide to control broadleaf weeds in crops such as potatoes (Solanum tuberosum L.), soybeans [Glycine max (L.) Merr.] and other vegetable crops. Highly water soluble $\left(1050 \mathrm{mg} \mathrm{L}^{-1}\right)$ and having a low adsorption coefficient $\left(\mathrm{K}_{\mathrm{oc}}=60\right)$, metribuzin shows moderate persistence in soil. Consequently, it may have the potential to leach into the soil profile and thus contaminate groundwater. Further, metribuzin was detected at the highest concentration of $25 \mu \mathrm{g} \mathrm{L}^{-1}$ in Lack Erie tributaries [26] and found to be the most frequently detected herbicide with a maximum concentration of $0.351 \mu \mathrm{g} \mathrm{L}^{-1}$ in 20 samples from drinking water wells in Brazil [27]. The half-life of metribuzin in soils ranges from 11 to 46 days in lab and field experiments; however, it was reported to be as long as 60-90 days under winter conditions in Manitoba [28]. In terms of the toxicity to aquatic plants, Fairchild et al. (1998) [29] stated that compared to atrazine, metolachlor and alachlor, metribuzin exhibits the highest level of toxicity. Similarly, metribuzin is highly toxic to freshwater macrophytes and algae under laboratory conditions (at $\mathrm{EC}_{50}=31 \mu \mathrm{g} \mathrm{L}^{-1}$ ) [30]. Recently, Plhalova et al. (2012) [31] investigated the effect of metribuzin in surface water on fish and found that the lowest observed effect concentration (LOEC) is $33 \mathrm{mg} \mathrm{L}^{-1}$.

Studies have shown that metribuzin dissipation is primarily dependent upon degradation by soil microorganisms [32-34]. Non-ionic surfactants are commonly used in herbicide formulations to enhance the herbicide penetration through the plant cuticle and thus increase its efficiency by reducing the loss of applied herbicide [35]. Since irrigation with wastewater can introduce large amounts of surfactants to soil, this could enhance the mobility of pesticides, such as metribuzin in soil water systems, by increasing their water solubility. To the best of the authors' knowledge, no study has investigated the fate and transport of metribuzin in the presence of rich surfactant irrigation water under field conditions and the potential contamination of ground water. Therefore, the aim of this study was to investigate the effect of the presence of the non-ionic surfactant Brij35 in irrigation wastewater at concentration above $\mathrm{CMC}$ on the downward movement of metribuzin in the soil profile and leachate.

\section{Material and Methods}

\subsection{Chemicals and Reagents}

A pure standard $\left(\right.$ Pestanal $^{\circledR}$ ) and formulation (Sencor 75 ) of metribuzin; trifluralin, used as an internal standard; the non-ionic surfactant Brij 35 [Polyoxyethylene lauryl ether $\left(\mathrm{C}_{2} \mathrm{H}_{4} \mathrm{O}\right)_{23}-\mathrm{C}_{12} \mathrm{H}_{25} \mathrm{OH}$ ] with critical micelle concentration $(\mathrm{CMC})=74 \mathrm{mg} \mathrm{L}^{-1}$; and HPLC-grade methanol and acetonitrile were obtained from Sigma-Aldrich. Mobile phase chemicals were purchased from Fisher Scientific. Double-deionized water (Milli-Q, Millipore, Molsheim, France) was used in the preparation of standard solutions and mobile phase solutions. 


\subsection{Soil Characteristics}

Belonging to the St. Amble complex, the sandy soil used was obtained from a field in the Macdonald Campus of McGill University, Ste-Anne-De-Bellevue, Quebec. Physical and chemical properties of soil are given in Table 1.

Table 1. Physical and chemical characteristics of soil.

\begin{tabular}{|c|c|c|c|c|c|c|c|}
\hline Soil Type & Sand $(\%)$ & Silt (\%) & pH & $\begin{array}{c}\text { Bulk Density } \\
\left(\mathrm{Mg} \mathrm{m}^{-3}\right)\end{array}$ & Organic Matter (\%) & $\begin{array}{c}\text { CEC } \\
\left(\mathrm{cmol} \mathrm{kg}^{-1}\right)\end{array}$ & $\begin{array}{c}\text { Hydraulic Conductivity } \\
(\mathrm{cm} \mathrm{Day} \\
\end{array}$ \\
\hline Sandy & 92.2 & 4.3 & 5.5 & 1.350 & 2.97 & 4.9 & $1.67(* \mathrm{SD}=0.45)$ \\
\hline
\end{tabular}

\subsection{Sorption Study}

Sorption of metribuzin onto soil in the presence of the non-ionic surfactant Brij 35 was investigated through a soil equilibrium technique. Triplicate soil samples $(1 \mathrm{~g})$ were equilibrated with an aqueous solution $(10 \mathrm{~mL})$ of metribuzin at concentrations of $\left(2.5,5.0,7.5\right.$ and $\left.12.5 \mu \mathrm{g} \mathrm{mL}{ }^{-1}\right)$ in factorial combination with Brij 35 concentrations of $0,0.5$ and $5 \mathrm{~g} \mathrm{~L}^{-1}$. All solutions contained $0.01 \mathrm{M} \mathrm{CaCl}_{2}$ to mimic the ionic strength of groundwater [36]. The soil slurry was placed in a $50 \mathrm{~mL}$ centrifuge tube, and placed on a reciprocal shaker, operating at $200 \mathrm{rpm}$, for $24 \mathrm{~h}$. The slurry was centrifuged at $2683 \mathrm{~g}$ for $20 \mathrm{~min}$. Extraction and analysis of metribuzin proceeded, as described above. The proportion of metribuzin adsorbed was calculated by taking the difference between the amount initially present in solution and the amount remaining in solution, after equilibrium with the soil.

The sorption coefficient was calculated as follows:

$$
K_{d}=\frac{C_{s}}{C_{a q}}
$$

where $C_{\mathrm{s}}$ is the amount of metribuzin sorbed $\left(\mu \mathrm{g} \mathrm{g}^{-1}\right), C_{\text {aq }}$ is the solution concentration in $\mu \mathrm{g} \mathrm{mL}^{-1}$, and $K_{d}$ is the sorption coefficient $\left(\mathrm{mL} \mathrm{g}^{-1}\right)$.

Organic carbon normalized coefficient values for metribuzin in the absence of surfactant and in the presence of surfactant were obtained as follows:

$$
K_{o c}=\frac{K_{d}}{f_{o c}}
$$

where $f_{\mathrm{oc}}$ is the organic carbon fraction of the soil $\left(0.0297 \mathrm{~g} \mathrm{~g}^{-1}\right.$ for the soil used), and $K_{\mathrm{oc}}$ is the partition coefficient of the contaminant in the organic fraction of the soil $\left(\mathrm{mL} \mathrm{g} \mathrm{g}^{-1}\right)$.

\subsection{Experimental Set $U p$}

The field experiment investigating metribuzin transport in a sandy agricultural soil was conducted in nine outdoor PVC lysimeters set up at the Macdonald Campus of McGill University, Ste-Anne-De-Bellevue, Quebec. The lysimeters were irrigated with three different levels of surfactants and applied in each lysimeter using the completely random design. The lysimeters were $(0.45 \mathrm{~m}$ O.D. $\times 1 \mathrm{~m}$ long $)$, sealed at the bottom to $0.6 \mathrm{~m} \times 0.6 \mathrm{~m}$ PVC sheets. Each was packed in 
layers with a sandy soil and adjusted to a bulk density of $1.35 \mathrm{mg} \mathrm{m}^{-3}$. A $0.05 \mathrm{~m}$ diameter drainage pipe was installed at the bottom of each lysimeter. Four, $10 \mathrm{~mm}$ diameter, soil sampling holes were made in each lysimeter at depths of $0.1,0.3$ and $0.6 \mathrm{~m}$ the soil surface (Figure 1). The lysimeters were sheltered to prevent entry of natural precipitation.

Figure 1. Schematic design of the lysimeter.
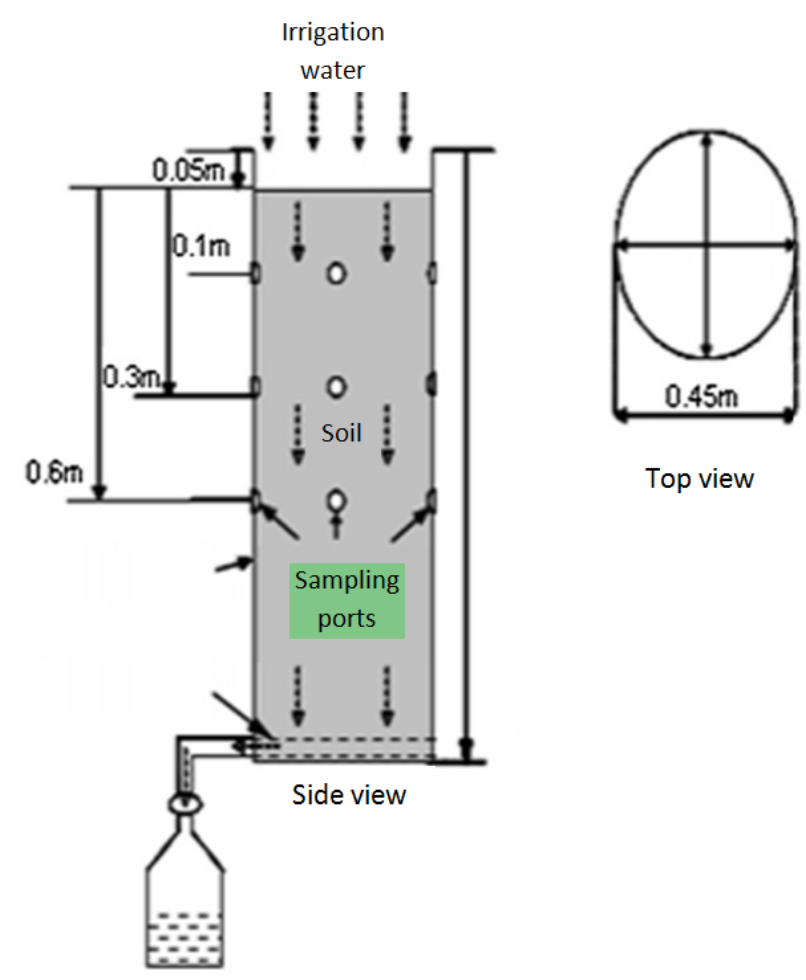

\subsubsection{Application of Tested Compounds}

Cattle manure was collected from an organic farm in Ham-Sud, Québec, at the end of June 2009. Before the start of the experiment, all lysimeters were irrigated, bringing them to saturation. The drainage pipe at the bottom of each lysimeter was left open throughout the study. The next day (Day 0), with the lysimeter's soil at field capacity, homogenized manure (10 $\left.\mathrm{mg} \mathrm{ha}^{-1}\right)$ was applied to the surface of all lysimeters and manually mixed into the top $30 \mathrm{~mm}$ of soil [37]. Metribuzin was then sprayed on to each lysimeter's soil surface (1 July 2009) at the locally recommended rate for potatoes (1 $\mathrm{kg}$ a.i. $\left.\mathrm{ha}^{-1}\right)$. Twelve liters $(70 \mathrm{~mm})$ of irrigation water, containing one of three different concentrations of Brij35 (0, 0.5 or $\left.5.0 \mathrm{~g} \mathrm{~L}^{-1}\right)$ was applied on day 0 , day 21, day 42, day 63, according to recommended irrigation practices for potatoes. Each treatment was replicated three times. While these surfactant concentrations may appear to be high, they are well within concentrations found in wastewater and industrial wastewater. Indeed, concentrations of up to $10 \mathrm{~g} \mathrm{~L}^{-1}$ have been used to study the effect of surfactants on atrazine movement in soils [38].

\subsubsection{Soil and Leachate Sampling}

Soil samples were collected at the surface as well as $0.1,0.3$ and $0.6 \mathrm{~m}$ beneath it, through 4 sampling ports in the side of the lysimeters. Soil samples were collected on 8 occasions: $0,1,5,11$, 
22, 43, 60 and 90 days after the application of manure. For each surfactant concentration, three replicate soil samples (3 lysimeters) were taken at each of the four depths, and samples from a common treatment $\times$ depth were combined in a composite sample $(\sim 15 \mathrm{~g})$. Subsamples of about $5 \mathrm{~g}$ were taken from each composite sample, and their moisture content was determined. The remaining portions of the samples were stored in sealed bags in the freezer at $-4{ }^{\circ} \mathrm{C}$ until extraction. Leachate samples (1 L) were collected as a subsample of a total of approximately 9-11 L of leachate, collected at the outlet at the bottom of each lysimeter, following each of the four irrigation events (Figure 1). The subsamples were then transported to the lab and immediately extracted to prevent any chance of metribuzin degradation.

\subsection{Mass Balance Calculations}

At each sampling date, total herbicide mass, recovered from each lysimeter, was calculated as the sum of herbicide recovered in soil samples across all depths of the soil profile. Adding the herbicide mass in the leachate to that in the soil would total the initial herbicide mass applied, minus any losses (unrecovered metribuzin ) due to degradation or volatilization (Equation (3)) [39].

$$
\begin{gathered}
M T R_{\text {init }}=1590.4 \rho\left[C_{(0-5)} \theta_{(0-5)} h_{(0-5)}+C_{(5-15)} \theta_{(5-15)} h_{(5-15)}+C_{(15-45)} \theta_{(15-45)} h_{(15-45)}\right. \\
\left.+C_{(45-70)} \theta_{(45-70)} h_{(45-70)}\right]+\left[C_{\text {leach }} V_{\text {leach }}\right]+M T R_{\text {lost }}
\end{gathered}
$$

where, (3) $M T R_{\text {init: }}$ Total metribuzin (mg) initially applied; $M T R_{\text {lost: }}$ Metribuzin lost through degradation, volatilization, etc. (mg); $\rho$ : Soil bulk density, $\left(\mathrm{g} \mathrm{cm}^{-3}\right) ; C_{(x-y)} \theta_{(x-y)} h_{(x-y)}$ : Metribuzin concentration and soil moisture content, respectively, in soil layer $h$ ranging from depth $x$ to depth $y$ $\left(\mathrm{mg} \mathrm{g}^{-1}\right) ; C_{\text {leach }}$ : Metribuzin concentration in leachate $\left(\mathrm{mg} \mathrm{L}^{-1}\right) ; V_{\text {leach }}$ : Volume of leachate; 1590.4: Soil layer surface area, $\pi\left(\frac{D}{2}\right)^{2}$, where $D=45 \mathrm{~cm}$.

In order to calculate the mass of metribuzin recovered in the soil layer samples, the following equation was used for this purpose:

$$
\text { Mass of MTR }=[C(\mathrm{~m})] \times \rho \times a \times h
$$

where $C$, laboratory reported analytical metribuzin concentration in soil samples $\left(\mathrm{mg} \mathrm{g}^{-1}\right)$; m, moisture content of soil samples (mass water/mass dry soil $\left.\mathrm{mg} \mathrm{g}^{-1}\right) ; \rho$, soil bulk density $\left(\mathrm{g} \mathrm{cm}^{-3}\right)$; $a$, area of lysimeter $\left(\mathrm{m}^{2}\right)$ and $h$, sampling depth of soil layers $(\mathrm{cm})$.

The half-life $t_{1 / 2}$ of metribuzin was calculated as follows:

$$
t_{\frac{1}{2}}=\frac{\ln 2}{k}
$$

Then Equation (6) is used in order to calculate k:

$$
C=C_{0} e^{-k t}
$$

where $C$, the metribuzin concentration at time $(t) ; C_{0}$, the initial metribuzin concentration and $k$ is the metribuzin degradation rate constant. 


\subsection{Analytical Methods}

\subsubsection{Leachate Sample Extraction}

Each $1 \mathrm{~L}$ subsample was filtered through $90 \mathrm{~mm}$ filter paper, followed by filtration through a $45 \mathrm{~mm}$ filter (Advantec, Dublin, CA, USA), to remove coarse and fine suspended matter, prior to extraction. Metribuzin-binding MCX cartridges (Oasis Co., Ltd., Milford, MA, USA) were used in solid phase extraction (SPE). Prior to this extraction, trifluralin was added to each of the filtered samples as an internal standard. Preconditioning of each cartridge began by passing $5 \mathrm{~mL}$ of water through each cartridge twice, then $5 \mathrm{~mL}$ of 50:50 water:methanol $(v / v)$, followed by $100 \%$ methanol,

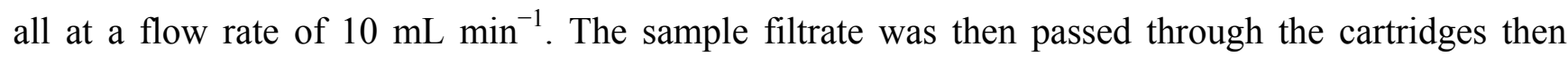
washed twice with $5 \mathrm{~mL}$ of water, to elute the metribuzin and trifluralin. Collected in a test tube, the $10 \mathrm{~mL}$ of eluate was evaporated under a $\mathrm{N}_{2}$ stream, residue redissolved in $1 \mathrm{~mL}$ of acetonitrile, then passed through $0.22 \mu \mathrm{m}$ syringe driven filter (Millex-GV, Billerica, MA, USA), and filtered solution transferred to a vial for HPLC analysis.

\subsubsection{Soil Sample Extraction}

In a $50 \mathrm{~mL}$ centrifuge tube, to each soil sample $(10 \mathrm{~g} \mathrm{FW}), 20 \mathrm{~mL}$ of ACS methanol was added, along with trifluralin as an internal standard, and the slurry was votexed for $30 \mathrm{~s}$. The tube was then placed in an ultrasonic bath for $15 \mathrm{~min}$, and then centrifuged at $2683 \mathrm{~g}$ for $20 \mathrm{~min}$. The supernatant was decanted and the extraction procedure was repeated twice more. The combined supernatants were passed through a $45 \mathrm{~mm}$ filter paper, and then evaporated under a $\mathrm{N}_{2}$ stream. Samples were redissolved in $1 \mathrm{~mL}$ of acetonitrile and passed through $0.22 \mu \mathrm{m}$ syringe driven filter prior to HPLC analysis.

\subsubsection{Analysis}

The soil samples and leachate were analyzed by HPLC, equipped with diode array detection (DAD) and an Eclipse plus $\mathrm{C}_{18}$ column $(4.6 \times 150 \mathrm{~mm}$; Agilent, Santa Clara, CA, USA). The mobile phase was acetonitrile and water, run as a gradient; 50:50 acetonitrile:water $(v / v)$ for 9 min then change to 10:90 acetonitrile:water $(v / v)$ for $8 \mathrm{~min}$. The flow rate was $1 \mathrm{~mL} \mathrm{~min}{ }^{-1}$ and the detection wavelengths were $238 \mathrm{~nm}$ and $254 \mathrm{~nm}$ for metribuzin and trifluralin, respectively. The extraction efficiency found to be $93 \%$ (representing 3 replicates from each concentration) and the detection limit of this method for the tested compound (metribuzin) was $10 \mathrm{ng} \mathrm{g}^{-1}$.

\subsection{Data Analysis}

A statistical model using repeated measures over time and depth was employed to determine if the metribuzin concentrations differed between treatments, over time and over depth. Data was analysed with PROC MIXED in SAS v. 9.2 [40]. 


\section{Results and Discussion}

\subsection{Sorption}

Among many factors affecting the transport of chemicals in soil, sorption plays an important role; therefore, sorption experiments in the presence and absence of Brij35 were carried out. Results revealed that the amount of metribuzin sorbed was higher in the absence of Brij35; however, it decreased in the presence of Brij35 at concentrations above CMC. The sorption isotherms of metribuzin in tap water and Brij35 solutions at concentrations of 0.5 and $5 \mathrm{~g} \mathrm{~L}^{-1}$ (Figure 2) all showed a good fit $\left(R^{2} \geq 0.97\right)$ with Equation (1). The $K_{\mathrm{d}}$ value for metribuzin shows the highest 1.80 in the absence of the surfactant; however, it decreases significantly to $(0.93$ and 1.38$)$ in the presence of Brij35 at 0.5 and $5 \mathrm{~g} \mathrm{~L}^{-1}$, respectively (Table 2). This indicates that the presence of micelles may enhance the release of sorbed metribuzin into the solution. Furthermore, a study by Sun et al. (1995) [41] revealed that non-ionic surfactants at concentration above CMC, decreased the sorption coefficient $K_{\mathrm{d}}$ of hydrophobic organic compounds (HOCs). Similarly, Chappell et al. (2005) [42] indicated that Brij35 at concentration above CMC competes with atrazine for sorption sites in soil leading to a significant decrease in atrazine sorption. Furthermore, the presence of surfactants enhanced the solubility of Trichloroethylene (TEC) and therefore, higher desorption rate of TEC in the aqueous medium has been observed [43].

Figure 2. Metribuzin isotherms in the absence and presence of the non-ionic surfactant Brij35.

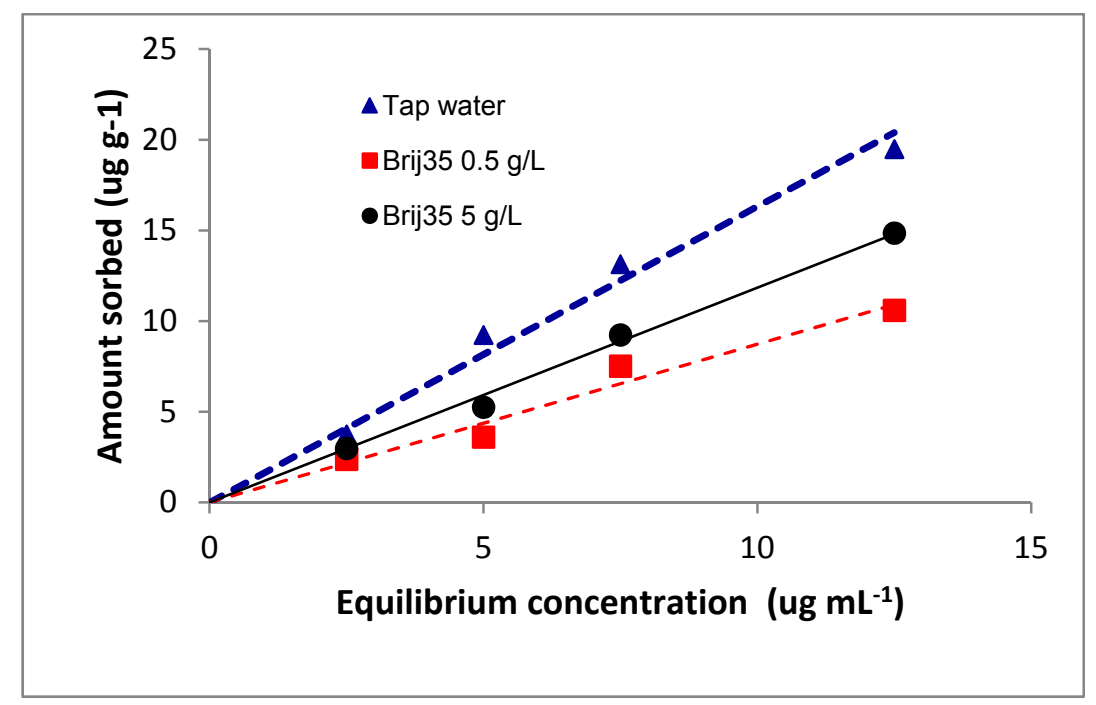

Table 2. Distribution coefficient $K_{\mathrm{d}}, R^{2}$ and $K_{\mathrm{oc}}$ values for metribuzin sorption in the presence of the nonionic surfactant Brij35.

\begin{tabular}{cccc}
\hline Concentration of Brij35 $\left(\mathbf{g ~ L}^{-1}\right)$ & $\boldsymbol{K}_{\mathbf{d}}$ & $\boldsymbol{R}^{\mathbf{2}}$ & $\boldsymbol{K}_{\mathbf{o c}}$ \\
\hline 0 & 1.8 & 0.97 & 60.61 \\
0.5 & 0.93 & 0.95 & 31.31 \\
5 & 1.38 & 0.99 & 46.46 \\
\hline
\end{tabular}


As a result of increasing the concentration of Brij35 from 0.5 to $5 \mathrm{~g} \mathrm{~L}^{-1}, K_{\mathrm{d}}$ values increased from 0.93 to 1.38 . This slight increase could be explained by the fact that at higher concentrations, non-ionic surfactant sorbed strongly to the soil and formed bilayers and since metribuzin has an affinity to partition with the hydrophilic head of Brij35, presumably via hydrogen bonding. This may lead to enhance metribuzin partitioning into the surfactant which is already sorbed to soil $[44,45]$. Therefore, increasing the $K_{\mathrm{d}}$ values at the highest Brij35 concentration of $5 \mathrm{~g} \mathrm{~L}^{-1}$ was observed. Furthermore, Nilufar (2005) [25] stated that the sorption coefficient of metribuzin $\left(K_{\mathrm{d}}\right)$ was $41 \%$ lower in the presence of the nonionic surfactant degradation product nonylephenol (NP) below CMC, confirming the desorption potential of NP for metribuzin.

The aqueous concentration of metribuzin increased once CMC is exceeded. This enhances micelles to form in the solution and compete with the sorbed surfactant for metribuzin. The more micelles present in the aqueous phase, the more metribuzin partitioning into the micelles within the solution, resulting in greater amount released from sorbed metribuzin. The present results are in agreement with the findings of [41,46]. Also, our results are in good match with Genari et al. (2009) [47] who indicated that the interaction between the surfactant and soil led to a competition with pesticides for adsorption sites, therefore a decline in pesticides adsorption was observed.

The distribution coefficient $K_{\mathrm{oc}}$, normalized to the corresponding soil organic carbon fraction $f_{\mathrm{oc}}$ and calculated from Equation (2), is found to follow the same trend as $K_{\mathrm{d}}$ values. Fundamentally, $K_{\mathrm{oc}}$ values have been used as an indicator of the leaching potential of herbicides such as atrazine and metribuzin [48]. In fact the $K_{\mathrm{oc}}$ value of 60.61 for metribuzin in the absence of Brij35 has been documented in the literature [49-51]. Obviously, the calculated $K_{\mathrm{oc}}$ values show a higher leaching potential for metribuzin in the presence of Brij35 (31.31-45.46) compared to the value of 60.61 in the absence of Brij35. This highlights the potential of non-ionic surfactants to enhance the desorption of metribuzin, either by solubilization or partitioning into the surfactant's micellar core.

\subsection{Mass Balance}

The mass balance for metribuzin is presented in Table 2. For all irrigation treatments, metribuzin concentrations were found to be below the detection limit by day 90 . In both the water and surfactant-irrigated treatments, the total amount of metribuzin detectable in the system (soil + leachate), declined from an initial (applied) level of about $20 \mathrm{mg}$ to less than $3 \mathrm{mg}$ after 63 days and four irrigations. The relative amount of metribuzin in the two lower soil depth layers (15-45 and 45-70 cm) to that in the upper layers $(0-5$ and 5-15 cm) was at least 2-fold greater in the presence of surfactants from Day 5 onwards, suggesting that a greater quantity of metribuzin leached downwards in the presence ( $v s$. absence) of the surfactant. This will be further addressed in the discussion of metribuzin residue concentrations in the soil which follows. 
Table 3. Amounts of metribuzin (mg) in different soil profile depth ranges, cumulated in leachate, and overall, over a 63 day period. Soil samplings on days $0,1,15,22,30$, and 60 at depths of $2,10,30$ and $60 \mathrm{~cm}$ depths, as well as and irrigations followed by leachate sampling on Days 1, 21, 42, 63. (-, metribuzin was below detection levels).

\begin{tabular}{|c|c|c|c|c|c|c|c|c|c|c|c|c|c|c|c|c|c|c|}
\hline \multirow{3}{*}{ Day } & \multicolumn{18}{|c|}{ Irrigation Solution Soil Profile Depth Range $(\mathrm{cm}) /$ Leachate/Total } \\
\hline & \multicolumn{6}{|c|}{ Tap water } & \multicolumn{6}{|c|}{ Brij35 at $0.5 \mathrm{~g} \mathrm{~L}^{-1}$} & \multicolumn{6}{|c|}{ Brij35 at $5 \mathrm{~g} \mathrm{~L}^{-1}$} \\
\hline & 0-5 & $5-15$ & 15-45 & $45-70$ & $\begin{array}{l}\text { Leach } \\
\text { cumul }\end{array}$ & Total & $0-5$ & 5-15 & 15-45 & $45-70$ & $\begin{array}{l}\text { Leach } \\
\text { cumul }\end{array}$ & Total & $0-5$ & 5-15 & 15-45 & $45-70$ & $\begin{array}{l}\text { Leach } \\
\text { cumul }\end{array}$ & Total \\
\hline 0 & 19.25 & \multicolumn{3}{|c|}{-Irrigation I- } & 0 & 19.25 & 19.85 & \multicolumn{3}{|c|}{-Irrigation I- } & 0 & 19.85 & 20.06 & \multicolumn{3}{|c|}{-Irrigation I- } & 0 & 20.06 \\
\hline 1 & 9.62 & 8.90 & - & - & 0.09 & 18.61 & 10.30 & 2.13 & 5.72 & - & 0.34 & 18.49 & 8.49 & 2.75 & 6.65 & - & 0.65 & 18.54 \\
\hline 5 & 5.05 & 3.08 & 0.94 & - & 0.09 & 9.16 & 4.91 & 1.79 & 2.55 & - & 0.34 & 9.59 & 2.82 & 2.26 & 3.52 & - & 0.65 & 9.25 \\
\hline 15 & 2.59 & 1.05 & 1.95 & - & 0.09 & 5.68 & 1.88 & 0.11 & 4.93 & 1.99 & 0.34 & 9.25 & 1.54 & 0.33 & 2.44 & 3.29 & 0.65 & 8.25 \\
\hline 21 & \multicolumn{4}{|c|}{ - Irrigation II-_ } & 0.17 & 5.76 & \multicolumn{4}{|c|}{ _Irrigation II-_ } & 0.80 & 9.71 & \multicolumn{4}{|c|}{-Irrigation II-_ } & 1.27 & 8.87 \\
\hline 22 & 1.32 & 0.21 & 1.36 & - & 0.17 & 3.06 & 0.78 & - & 1.60 & 1.72 & 0.80 & 4.90 & 0.95 & - & 0.91 & 1.09 & 1.27 & 4.22 \\
\hline 30 & 0.85 & - & - & - & 0.17 & 1.02 & 0.62 & - & 0.82 & 0.56 & 0.80 & 2.80 & 0.22 & - & 1.20 & 1.08 & 1.27 & 3.77 \\
\hline 42 & \multicolumn{4}{|c|}{ _Irrigation III-_ } & 0.25 & 1.10 & \multicolumn{4}{|c|}{-Irrigation III-_- } & 1.33 & 3.33 & \multicolumn{4}{|c|}{ _- Irrigation III-_ } & 1.55 & 4.05 \\
\hline 60 & 0.12 & - & - & - & 0.25 & 0.37 & 0.09 & - & - & 0.93 & 1.33 & 2.35 & 0.07 & - & - & 0.17 & 1.55 & 1.79 \\
\hline 63 & \multicolumn{4}{|c|}{ Irrigation IV_- } & 0.25 & 0.37 & \multicolumn{4}{|c|}{ _-Irrigation IV_- } & 1.54 & 2.56 & \multicolumn{4}{|c|}{ _Irrigation IV_- } & 1.55 & 1.79 \\
\hline
\end{tabular}


From 15 days onward, the total amount of measured metribuzin was higher in the treatments of surfactant compared to the tap water (Table 3). After 60 days, the total residual metribuzin was 4 and 6 fold greater in the 5 and $0.5 \mathrm{~g} \mathrm{~L}^{-1}$ treatments, respectively, than in the tap water treatment. The percentage of unrecovered metribuzin (Figure 3) was similar for all three irrigation types up to 5 days; however, later values were smaller in the presence of surfactant. As a result, greater recoveries have been measured in the presence of the non-ionic surfactant Brij35 compared to tap water treatment. Despite the fact that metribuzin is mobile in soil, previous studies detected no amount of metribuzin in leachate from lysimeters packed with sandy soil and irrigated with tap water [25,52]. However, in the present study, $0.34 \%$ of the applied metribuzin was recovered in the leachate of lysimeters irrigated with tap water, and $1.86 \%$ and $2.04 \%$, respectively, for the 0.5 and $5.0 \mathrm{~g} \mathrm{~L}^{-1}$ surfactant treatments.

Figure 3. Metribuzin lost percentage in the season in the absence and presence of surfactant.

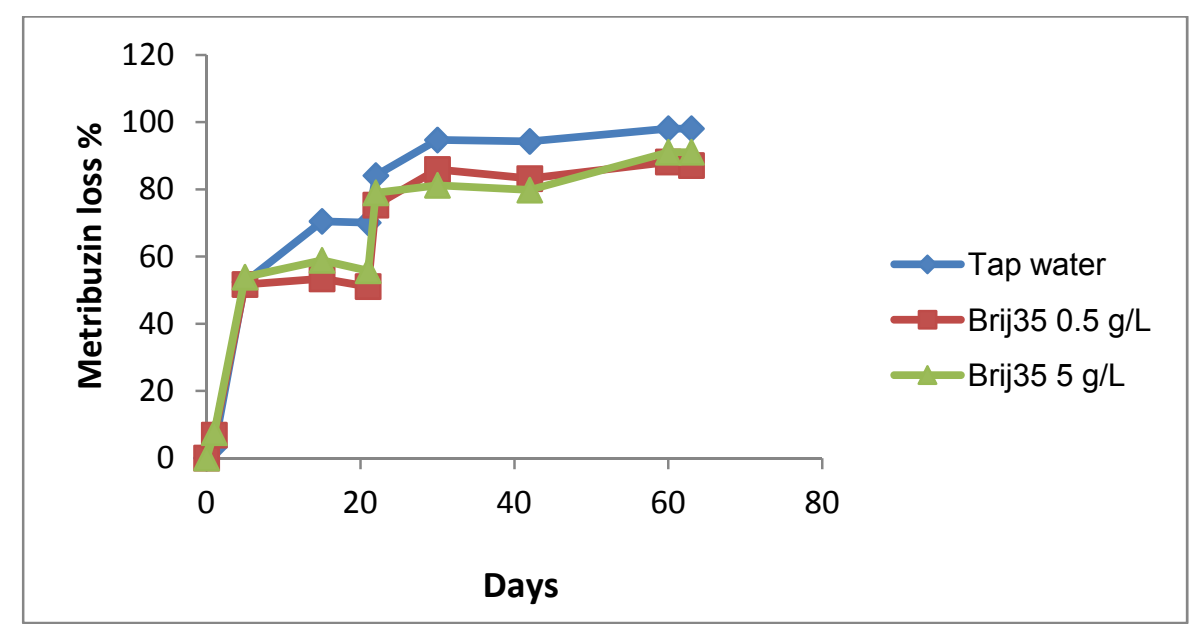

Degradation of pesticides has been extensively studied and revealed the fact that some factors other than leaching, can significantly affect the breakdown of metribuzin in soil and water. These factors could be sorption, microbial degradation and photolysis [53]. In general, several studies have indicated that the microbial activity plays a major role in the degradation process of metribuzin in soil $[54,55]$. More specifically, soil microorganisms have the ability to transform metribuzin to its metabolites; desaminometribuzin (DA), desaminodiketometribuzin (DADK), and diketometribuzin (DK) [56]. In sewage effluents, In the case of non-ionic surfactants, they are subject to biodegradation and produce intermediates which are generally less water soluble such as polyethylene glycols (PEG) and carboxylic aerobic metabolites i.e., carboxylated PEGs [57].

In terms of the amount of unrecovered metribuzin in soil, results showed that in the presence of surfactant, the amount of unrecovered metribuzin was less than the one in the tap water treatment indicating that the non-ionic surfactant could have influenced metribuzin degradation in soil. As indicated in (Figure 3) the presence of surfactant reduced the loss of metribuzin. This may be explained by the findings of Laha and Luthy (1992) [58] that showed a decrease in phenanthrene degradation in the presence of non-ionic surfactants above CMC compared to those below CMC. They assumed that micelles can hold the pesticide from transporting to bacterial cells resulting in an inhibition of bactaerial mineralization of the pesticide. Similarly, comparing to Brij30 and Triton $\mathrm{X}-100$, Brij35 reduced the bioavailability of phenanthrene as a result of the deficient interaction 
between the hydrophilic moiety of Brij35 (long polyethoxy chain) and bacterial cell membrane [59]. This assumption has been confirmed by Allen et al. (1999) [60] who found that cell disruption of microbes is the main cause of inhibition of PAHs degradation, in the presence of nonionic surfactant, Triton X-100.

\subsection{Effect of Nonionic Surfactant Brij35 on Metribuzin Residues in Soil}

The repeated measures analysis showed the effect of treatment (surfactant concentration), depth and time, as well as their single and multiple interactions were all significant $(p \leq 0.05)$. Mean metribuzin concentrations in soil over a 90-day period for the soil surface and at 0.1, 0.3 and $0.6 \mathrm{~m}$ soil depths are illustrated in Figures 4-7. As expected, the metribuzin concentration was highest at the soil surface and dropped significantly as sampling depth increased. At the soil surface, the concentration decreased as the degradation rate increased with time. The concentrations right after the first application on day 1 were 968.68, 1036.34 and $854.93 \mu \mathrm{g} \mathrm{kg}^{-1}$ in the treatments with tap water, Brij35 $0.5 \mathrm{~g} \mathrm{~L}^{-1}$ and Brij35 $5 \mathrm{~g} \mathrm{~L}^{-1}$, respectively. Metribuzin levels declined over time and reached $12.37 \mu \mathrm{g} \mathrm{kg}^{-1}$ in the topsoil on day 60 for the tap water treatment, whereas for Brij35 $0.5 \mathrm{~g} \mathrm{~L}^{-1}$ and Brij35 $5 \mathrm{~g} \mathrm{~L}^{-1}$, concentrations were lower at 9.82 and $7.29 \mu \mathrm{g} \mathrm{kg}^{-1}$, respectively. By day 90 , metribuzin concentration in the topsoil was below the detection limit for all irrigation treatments. However, a considerable amount of metribuzin leached to the next depths in the treatments with surfactants. This result for the tap water treatment concurs with the findings of several studies [61-65]. They reported that metribuzin concentrations declined in topsoil immediately after application. A number of studies suggest that a significant portion of this decline can be attributed to the presence of soil microorganisms, which play a significant role in the breakdown of metribuzin in soil $[66,67]$. For all treatments, metribuzin degradation is shown to follow the first order kinetic $[68,69]$. Typically, a rapid initial dissipation is followed by a gradual decline in the degradation rate and eventually a relatively slow long term breakdown. The half-life of metribuzin under the experiment conditions is calculated. In the tap water treatment, the half- life of metribuzin was 8.89 days; however, it decreased to 8.35 and 7.96 days in the treatment of surfactant at 0.5 and $5.0 \mathrm{~g} \mathrm{~L}^{-1}$, respectively. This is consistent with the reported half -life by Webster and Reimer (1979) [28].

At the $0.1 \mathrm{~m}$ depth, initial metribuzin concentrations in the tap water treatment were higher than those in either of the Brij35 treatments. For all treatments, metribuzin levels decreased over time; however, in the tap water treatment, metribuzin was detectable through day 22, whereas in the Brij35 treatments it only remained detectable through day 15. This disappearance of metribuzin could be attributed to its movement to lower depths and to the microbial degradation. Metribuzin breakdown varies according to soil layers [69] due to the differences in their microbial populations. Indeed, Bouchard et al. (1982) and Danial et al. (2002) [62,70] observed that metribuzin degradation is decreased by depth. Likewise, Fan (2010) [52] conducted a lysimeter study and observed that a considerable amount of surface-applied metribuzin had migrated through a sandy soil to a depth greater than $0.1 \mathrm{~m}$ within the first 7 days, and then decreased gradually afterwards. Similarly, results from a study investigating the mobility of metribuzin under free drainage conditions, revealed that a significant portion of surface-applied metribuzin was detected below a $0.1 \mathrm{~m}$ soil depth, six days after application [71]. 
Figure 4. Metribuzin concentrations at the surface.

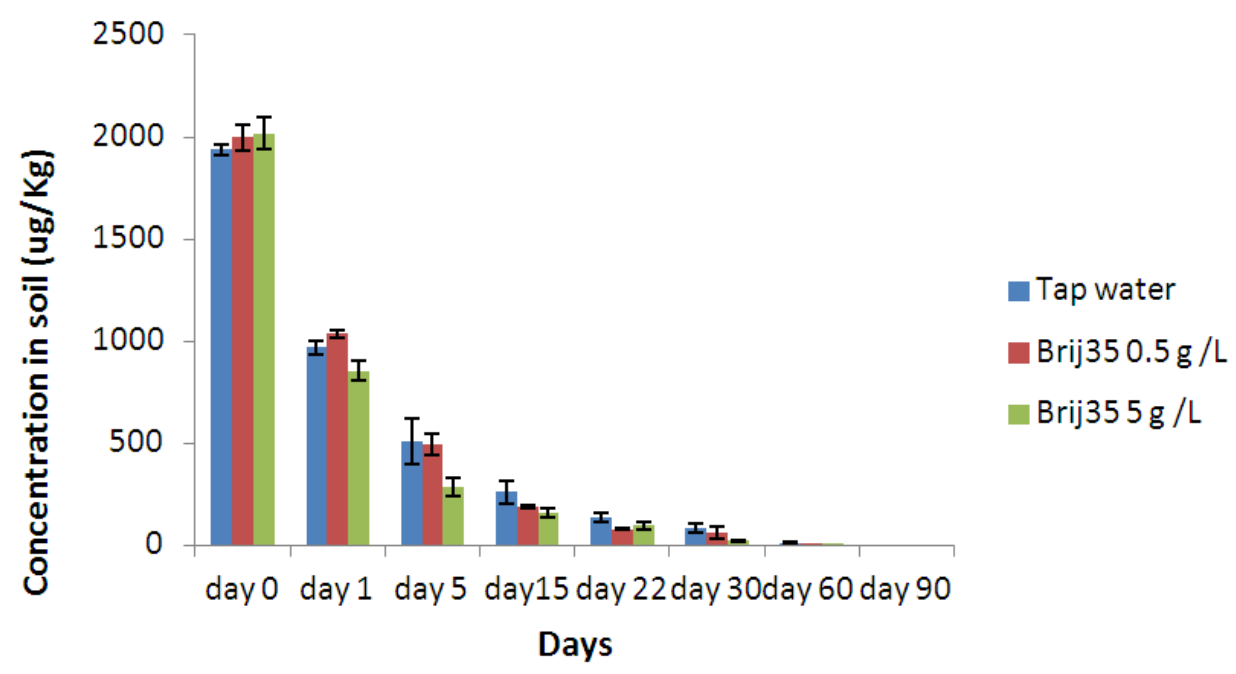

Figure 5. Metribuzin concentrations at $0.1 \mathrm{~m}$ depth.

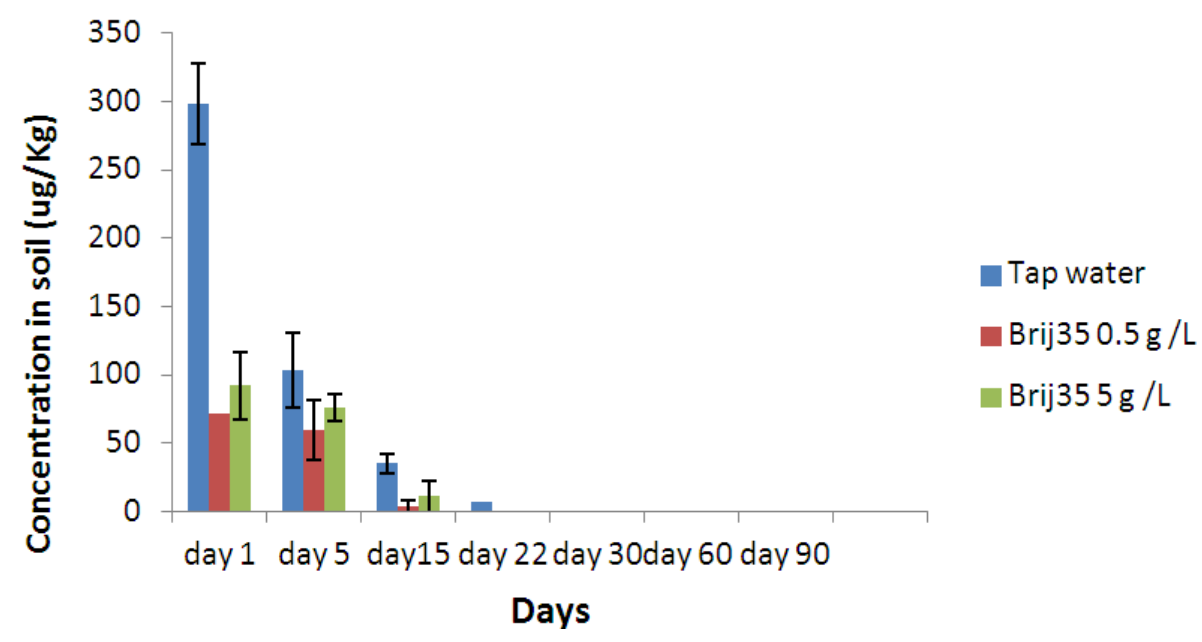

Figure 6. Metribuzin concentrations at $0.3 \mathrm{~m}$ depth.

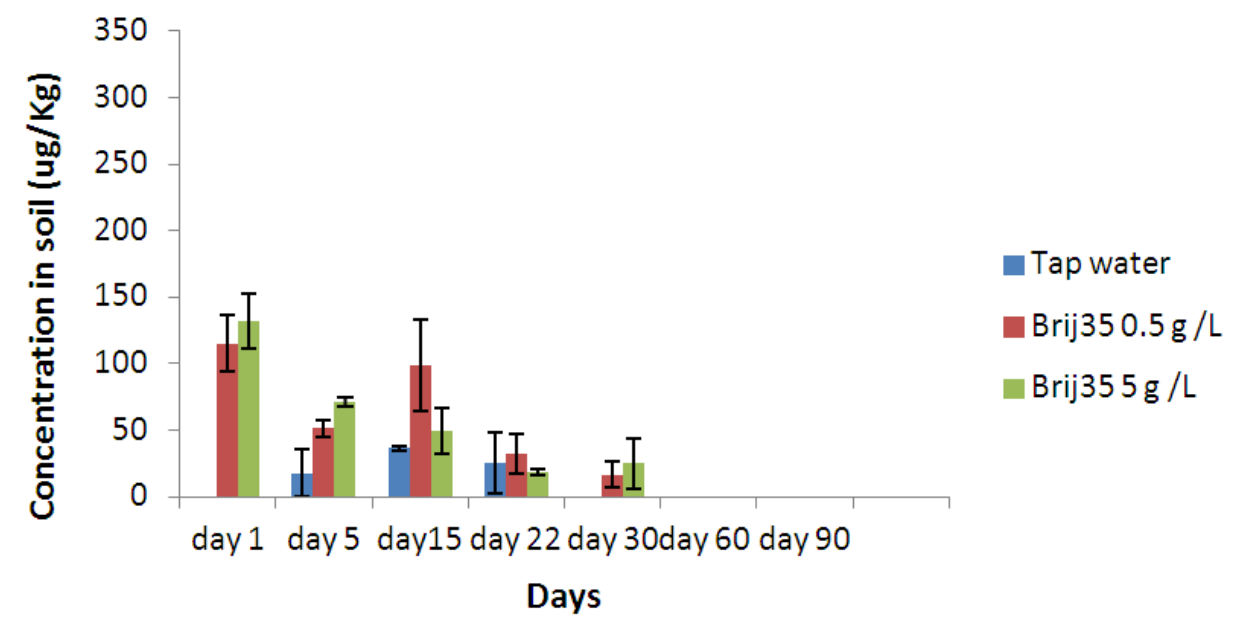


Figure 7. Metribuzin concentrations at $0.6 \mathrm{~m}$ depth.

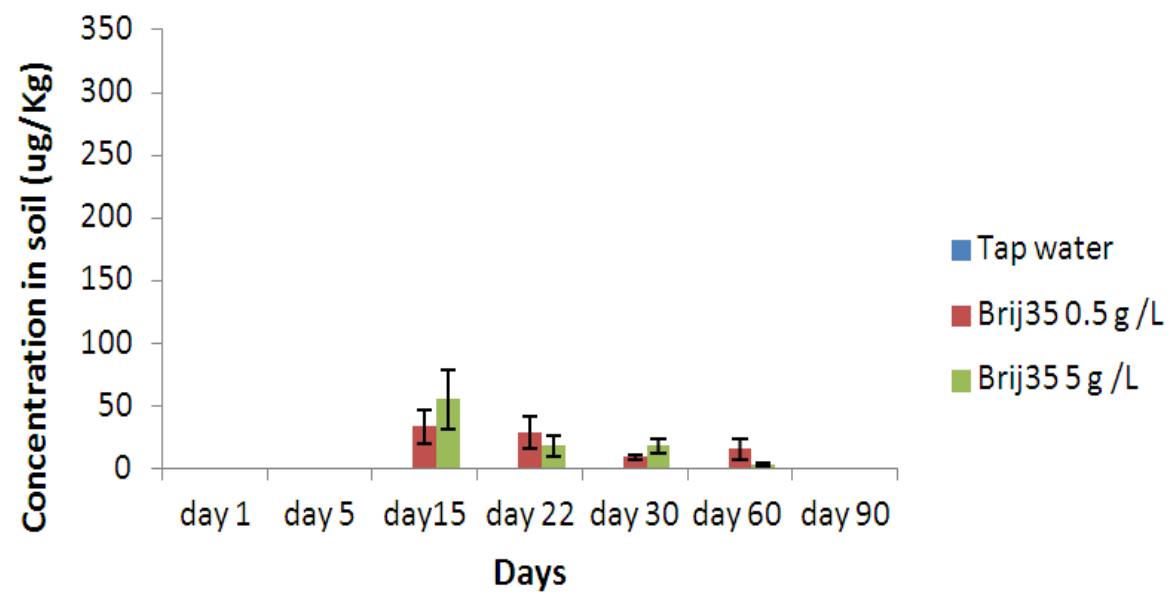

At the $0.3 \mathrm{~m}$ depth, the effect of surfactant treatments contrasted with the $0.1 \mathrm{~m}$ depth, since metribuzin concentrations were higher in the presence of surfactant compared to the tap water (Figure 6). This indicates that Brij35 influenced the downward movement of metribuzin. Given that metribuzin is a non-ionic compound, belonging to the weakly basic triazines, its sorption to soil is dependent on the amount of organic matter, clay content and $\mathrm{pH}$. It was reported that metribuzin showed a great potential for leaching in soil [51,70]. At the $0.6 \mathrm{~m}$ depth, low concentrations of metribuzin (33.46-2.87 $\mu \mathrm{g} \mathrm{kg}^{-1}$ ) were detected from day 15 to day 60, in the Brij35 treatments, but remained below detection limits for the tap water treatment. This highlights the role of surfactants in enhancing metribuzin mobility in the soil profile (Figure 7). The decrease in metribuzin concentrations over time and depth was reflected by the significant effects $(p \leq 0.05)$ of treatment, depth, time and their interactions. Results for tap water concurred with the results of columns studies conducted by Bedmar et al. (2004) and Maqueda et al. (2009) [51,67]. They indicated the absence of metribuzin in soil samples from soil depths exceeding $0.30 \mathrm{~m}$. Moreover, as the solubility of the herbicide increased, its ability to compete with organic surfaces decreased. This accounts for why, in certain conditions, the migration of metribuzin downward through the soil profile was improved [72].

Generally, surfactants play an important role in enhancing the mobility of pesticides and this fact has been confirmed by Muller et al. (2007) and Zhang et al. (2011) [43,73]. Our study also showed a greater downward movement of metribuzin through a sandy soil in the presence ( $v s$. absence) of the non-ionic surfactant Brij35. Generally, surfactants can increase the solubility of pesticides through their solubilization in the micelles, which formed above the critical micelle concentration (CMC) of the surfactant. Depending on this concentration, pesticide properties, the degree and the location of solubilization into the micelle, surfactant effects can vary. Since metribuzin is a polar herbicide, it is expected to be solubilized by the surfactant once CMC is exceeded. Furthermore, depending on their hydrophilicity, non-ionic surfactants have the ability to solubilize polar compounds [74]. This hydrophilicity is known to be governed by the number of the ethylene oxide groups (EO) in the surfactant molecule, i.e., the greater the number of EO groups, the more hydrophilic the surfactant [75]. Since Brij35 has twenty-three EO groups, it is expected to exhibit a high capacity to solubilise polar compounds, such as metribuzin in the environment. 


\subsection{Effect of Non-Ionic Surfactant Brij35 on Metribuzin in Leachate}

The leachate samples were analyzed to quantify the amount of metribuzin leaching to shallow ground water. Metribuzin concentrations in the leachate of both Brij35 treatments, ranging from 67.22 to 23.02 for Brij35 at $0.5 \mathrm{~g} \mathrm{~L}^{-1}$, and $84.80 \mu \mathrm{g} \mathrm{L}^{-1}$ to below the detection limit for Brij35 at $5 \mathrm{~g} \mathrm{~L}^{-1}$ (Figure 8). The levels of metribuzin in the leachate were significantly greater at the treatment of Brij35 at $5.0 \mathrm{~g} \mathrm{~L}^{-1}$ than Brij35 at $0.5 \mathrm{~g} \mathrm{~L}^{-1}$ after the first two irrigation events. Metribuzin concentrations reached a maximum at the third application $\left(17.19 \mu \mathrm{g} \mathrm{L}^{-1}\right)$ in the tap water leachate samples. This observation can be explained by the fact that metribuzin adsorption in sandy soil is reversible and thus residues might escape to lower layers in the soil profile [67]. Likewise, since sandy soil possess a low CEC and large pore spaces, high leaching potential for herbicides may be observed [76]. However, in a lysimeter study, no metribuzin concentrations were detected in the leachate from a sandy soil after irrigation with either tap water or a non-ionic surfactant metabolite, NP (12 mg L $\left.{ }^{-1}\right)$ [25].

Figure 8. Metribuzin concentrations in Leachate.

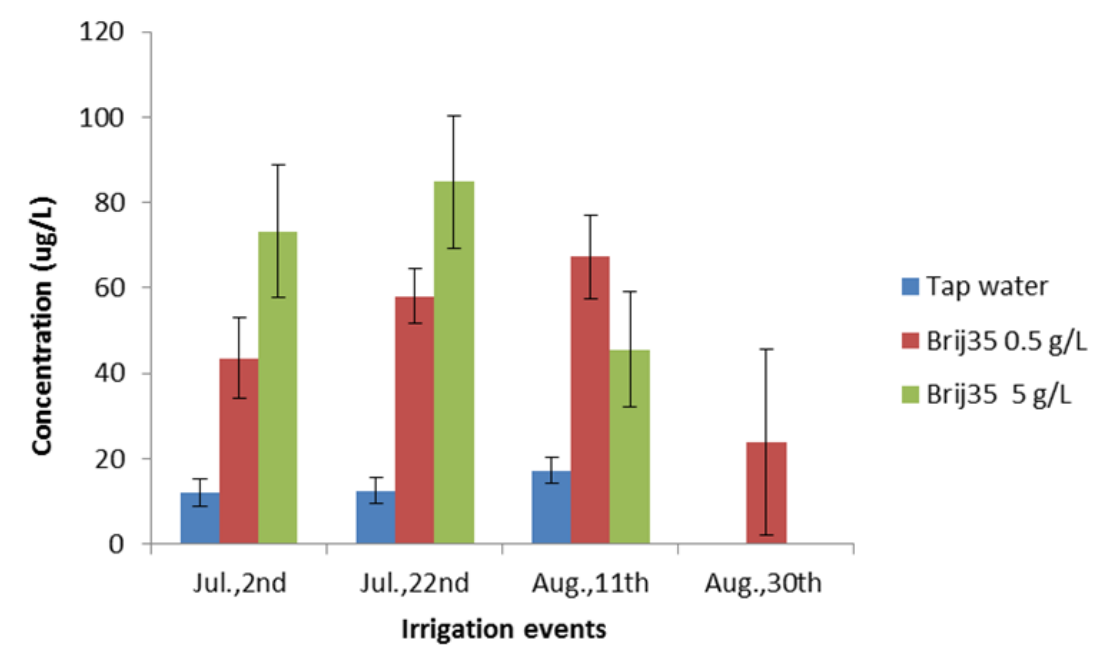

In the case of surfactant treatments, the amount of metribuzin moved from the surface to the leachate in the treatment of Brij35 at $5 \mathrm{~g} \mathrm{~L}^{-1}$ was $84.80 \mu \mathrm{g} \mathrm{L}^{-1}$ after the second irrigation event. This amount exceeded the acceptable level for metribuzin in drinking water $\left(80 \mu \mathrm{g} \mathrm{L}^{-1}\right)$, according to Canadian guidelines [77]. Generally, above the CMC, the lipophilic end (alkyl chain) of the surfactant molecule aggregate together inside the micelle, with the hydrophilic end point towards the aqueous phase on the exterior [78]. Thus, micelles enhance the solubility of low polarity organic compounds by partitioning them into the hydrophobic micelle core. Since metribuzin is a polar herbicide, it is expected to be attracted by the polar head of the surfactant by hydrogen bonding. Partitioning of pesticides with surfactants is well documented in the literature [46,79,80]. More specifically, polar compounds, such as pesticides, are solubilized in the neighborhood of stern layer of the surfactant [22]. Additionally, non-ionic alcohol ethoxylates (AE) are found to enhance the downward movement of pesticides when applied at high (vs. low) concentrations to soil columns [18].

Typically, sorption of herbicides onto soil surfaces occurs when the polar components in soil interact with the polar functional groups of the herbicide and since metribuzin has an amide group, interaction with polar sites may occur. However, if water is present, metribuzin tends to interact with 
water molecules via hydrogen bonding and form hydrophilic complexes, which in turn, facilitate the leaching process. This may explain the relationship between its solubility and leaching potential [81]. Since surfactants can interact with soil, it may compete with metribuzin for available binding sites in soil. This can lead to enhance the free downward movement of metribuzin in soil profile. Recently, Undabeytia et al. (2011) [82] confirmed the role of polar groups (amide) in metribuzin in the formation of water bridges via hydrogen bonding with the hydrophilic head of the non-toxic surfactant phosphatidylcholine in clay formulations. Therefore, in the presence of a non-ionic surfactant, such as Brij35at concentrations above its $\mathrm{CMC}$, metribuzin would be captured by micelles, with its polar groups oriented toward the polar head (EO) of the micelles, which would exhibit a strong hydrophilic interaction via hydrogen bonding or dipole-dipole effects. In the present study, results of the lysimeter experiment are explained by the findings of the sorption study. This conclusion confirms the role of non-ionic surfactant Brij35 in decreasing the sorption coefficient of metribuzin and hence promoting its release from soil. Therefore, additional research should be carried out to better understand the effect of chemical compounds when they coexist as mixtures in the environment.

\section{Conclusions}

Understanding the mobility of metribuzin within soil-water-surfactant systems is an important step in evaluating the risk resulting from irrigation with wastewater. The present study showed the presence of non-ionic surfactant (Brij35) in concentrations higher than its CMC, increased the downward movement of metribuzin in the soil profile, presumably due to the solubilization power of micelles in the soil-water system when Brij35 was present at 0.5 or $5 \mathrm{~g} \mathrm{~L}^{-1}$ or the competition between the surfactant and metribuzin for soil binding sites. Additionally, metribuzin concentrations in the leachate were higher (about 5 times) in the presence of Brij35 compared to the tap water. In spite of the fact that metribuzin is water soluble, other lysimeter studies have shown metribuzin to rarely move below $30 \mathrm{~cm}$ depth in the soil profile. The present study indicates that the presence of a non-ionic surfactant in irrigation water increased the mobility of metribuzin in soil and led to its presence in leachate samples at a depth of $1 \mathrm{~m}$ below the soil. Therefore, the continuous use of wastewater containing non-ionic surfactants at concentrations exceeding their $\mathrm{CMC}$ can be expected to increase the possibility of pesticides being detected in leachate, eventually reaching ground water, and thus potentially contaminating water resources.

\section{Acknowledgments}

The authors would like to acknowledge the financial support provided by Faculty of Agriculture, Zagazig University, Egypt and the Natural Sciences and Engineering Research Council of Canada (NSERC). The authors thank R.M. Patel (Research associate in the department of Bioresource Engineering, McGill University, Montreal, Canada) for his guidance in the field experiments. 


\section{References}

1. Comprehensive Assessment of the Freshwater Resources of the World; World Meteorological Organization: Geneva, NY, USA, 1997.

2. Rahman, S.H.; Khanam, D.; Adyel, T.M.; Islam, M.S.; Ahsan, M.A.; Akbor, M.A. Assessment of heavy metal contamination of agricultural soil around dhaka export processing zone (DEPZ), bangladesh: Implication of seasonal variation and indices. Appl. Sci. 2012, 2, 584-601.

3. Chatterjee, S.N. Fresh produce from wastewater. Environ. Sci. Technol. 2008, 42, 7732.

4. Drechsel, C.; Raschid-Sally, L.; Redwood, M.; Bahri, A. Water Irrigation and Health. Assessing and Mitigating Risk in Low-Income Countries; Earthscan/IDRC: London, UK, 2010.

5. Hamilton, A.J.; Stagnitti, F.; Xiong, X.; Kreidl, S.L.; Benke, K.K.; Maher, P. Wastewater irrigation: The state of play. Vadose Zone J. 2007, 6, 823-840.

6. Brunner, P.H.; Capri, S.; Marcomini, A.; Giger, W. Occurrence and behavior of linear alkylbenzenesulphonates, nonylphenol, nonylphenol mono- and nonylphenol diethoxylates in sewage and sewage sludge treatment. Water Res. 1988, 22, 1465-1472.

7. Field, J.A.; Leenheer, J.A.; Thorn, K.A.; Barber, L.B.; Rostad, C.; Macalady, D.L.; Daniel, S.R. Identification of persistent anionic surfactant derived chemicals in sewage effluent and ground water. J. Contam. Hydrol. 1992, 9, 55-78.

8. Wild, S.B.; Waterrath, K.S.; Jones, K.F. Organic contaminants in an agricultural soil with a known history of sewage sludge amendments. Environ. Sci. Technol. 1990, 24, 1706-1711.

9. Narkis, N.; Ben-David, B. Adsorption of nonionic surfactants on active carbon and mineral clay. Water Res. 1985, 19, 815-824.

10. Castillo, M.; Alonso, M.C.; Riu, J.; Barcelo, D. Identification of polar, ionic, and highly water soluble organic pollutants in untreated industrial wastewaters. Environ. Sci. Technol. 1999, 33, 1300-1306.

11. Feitkenhauer, H.; Meyer, U. On-line titration of non-ionic surfactants in wastewater treatment plants using a specific electrode. Water Sci. Technol. 2002, 45, 61-68.

12. Zoller, U. Non-ionic surfactants in reused water: Are activated sludge/soil aquifer treatments sufficient? Water Res. 1994, 28, 1625-1629.

13. Loyo-Rosales, J.E.; Rice, C.P.; Torrents, A. Fate of octyl and nonylphenol ethoxylates and some carboxylated derivatives in three american wastewater treatment plants. Environ. Sci. Technol. 2007, 41, 6815-6821.

14. Bhandari, A.; Surampalli, R.Y.; Adams, G.D.; Champagne, P.; Ong, S.K.; Tyagi, R.D.; Zhang, T. Contaminats of Emerging Environmental Concern; The American Society of Civil Engineers: Reston, VA, USA, 2009.

15. Conn, K.E.; Barber, L.B.; Brown, G.K.; Siegrist, R.L. Occurrence and fate of organic contaminants during onsite wastewater treatment. Environ. Sci. Technol. 2006, 40, 7358-7366.

16. Esperanza, M.; Suidan, M.T.; Nishimura, F.; Wang, Z.; Sorial, G.A. Determination of sex hormones and nonylphenol ethoxylates in the aqueous matrixes of two pilot-scale municipal wastewater treatment plants. Environ. Sci. Technol. 2004, 38, 3028-3035. 
17. Barber, L.B.; Keefe, S.H.; Leblanc, D.R.; Bradley, P.M.; Chapelle, F.H.; Meyer, M.T.; Loftin, K.A.; Kolpin, D.W.; Rubio, F. Fate of sulfamethoxazole, 4-Nonylphenol, and 17-Estradiol in groundwater contaminated by wastewater treatment plant effluent. Environ. Sci. Technol. 2009, $43,4843-4850$.

18. Huggenberger, F.H.; Letey, J.; Farmer, W.J. Effect of two nonionic surfactants on adsorption and mobility of selected pesticides in a soil-system. Soil Sci. Soc. Am. Proc. 1973, 37, 215-219.

19. Kan, T.A.; Tomson, M.B. Ground water transport of hydrophobic organic compounds in the presence of dissolved organic matter. Environ. Toxicol. Chem. 1990, 9, 253-263.

20. Aronstein, B.N.; Calvillo, Y.M.; Alexander, M. Effect of surfactants at low concentrations on the desorption and biodegradation of sorbed aromatic compounds in soil. Environ. Sci. Technol. 1991, $25,1728-1731$.

21. Rodriguez-Cruz, M.S.; Sanchez-Martin, M.J.; Sanchez-Camazano, M. Enhanced desorption of herbicides sorbed on soils by addition of Triton X-100. J. Environ. Qual. 2004, 33, 920-929.

22. Katagi, T. Surfactant effects on environmental behavior of pesticides. Rev. Environ. Contam. Toxicol. 2008, 194, 71-177.

23. Tao, Q.; Dong, S.; Hong, X.; Wang, T. Effect of surfactants at low concentrations on the sorption of atrazine by natural sediment. Water Environ. Res. 2006, 78, 653-660.

24. Sanchez-Camazano, M.; Arienzo, M.; Sanchez-Martin, M.J.; Crisanto, T. Effect of different surfactants on the mobility of selected non-ionic pesticides in soil. Chemosphere 1995, 31, 3793-3801.

25. Nilufar, F. Fate and Transport of Herbicides in Soil in the Presence of Surfactants in the Irrigation Water. Master's Thesis, McGill University, Montreal, Canada, November 2005.

26. Richards, R.P.; Baker, D.B. Pesticide concentration patterns in agricultural drainage networks in the Lake Erie basin. Environ. Toxicol. Chem. 1993, 12, 13-26.

27. Dores, E.F.G.C.; Navickiene, S.; Cunha, M.L.F.; Carbo, L.; Ribeiro, M.L.; de-Lamonica-Freire, E.M. Multiresidue determination of herbicides in environmental waters from Primavera do Leste region (Middle West of Brazil) by SPE-GC-NPD. J. Braz. Chem. Soc. 2006, 17, 866-873.

28. Webster, G.R.B.; Reimer, G.J. Field degradation of the herbicide metribuzin and its degradation products in a Manitoba sandy loam soil. Weed Res. 1976, 16, 191-196.

29. Fairchild, J.F.; Ruessler, D.S.; Carlson, A.R. Comparative sensitivity of five species of macrophytes and six species of algae to atrazine, metribuzin, alachlor, and metolachlor. Environ. Toxicol. Chem. 1998, 17, 1830-1834.

30. Fairchild, J.F.; Sappington, L.C. Fate and effects of the triazinone herbicide metribuzin in experimental pond mesocosms. Arch. Environ. Contam. Toxicol. 2002, 43, 198-202.

31. Plhalova, L.; Stepanova, S.; Praskova, E.; Chromcova, L.; Zelnickova, L.; Divisova, L.; Skoric, M.; Pistekova, V.; Bedanova, I.; Svobodova, Z. The effects of subchronic exposure to metribuzin on Danio rerio. Sci. World J. 2012, 2012, doi:10.1100/2012/728189.

32. Ladlie, J.S.; Meggitt, W.F.; Penner, D. Effect of soil pH on microbial degradation, adsorption, and mobility of metribuzin. Weed Sci. 1976, 24, 477-481.

33. Sharom, M.S.; Stephenson, G.C. Behaviour and fate of metribuzin in eight Ontario soils. Weed Sci. 1976, 24,153-160. 
34. Khoury, R.; Geahchan, A.; Coste, C.M.; Antoun, M.A. The Behavior of Pesticide in Soil: The Influence of Various Environmental Factors on the Degradation of Metribuzin. In Proceedings of 2000 Mediterranean Conference for Environment and Solar, Beirut, Lebanon, 16-17 November 2000; pp. 34-39.

35. Ramsey, R.J.L.; Stephenson, G.R.; Hall, J.C. A review of the effects of humidity, humectants, and surfactant composition on the absorption and efficacy of highly water-Soluble herbicides. Pestic. Biochem. Physiol. 2005, 82, 162-175.

36. Wilde, D.T.; Mertens, J.; Spanoghe, P.; Ryckeboer, J.; Jaeken, P.; Springael, D. Sorption kinetics and its effects on retention and leaching. Chemosphere 2008, 72, 509-516.

37. Chettri, M.; Thapa, U. Integrated nutrient management with farm yard manure on potatos (Solanum tuberosum) under gangetic plains of west Bengal. Environ. Ecol. 2004, 22, 766-769.

38. Abu-Zreig, M.; Rudra, R.P.; Dickinson, W.T.; Evans, L.J. Effect of surfactants on sorption of atrazine by soil. J. Contam. Hydrol. 1999, 36, 249-263.

39. ElSayed, E.M.; Prasher, S.O.; Patel, R.M. Effect of nonionic surfactant Brij35 on the fate and transport of oxytetracycline antibiotic in soil. J. Environ. Manag. 2013, 116, 125-134.

40. SAS/GRAPH, 2nd ed.; SAS Institute Inc.: Cary, NC, USA, 2010.

41. Sun, S.; Inskeep, W.P.; Boyd, S. Sorption of nonionic compounds in soil-water systems containing a micelle-forming surfactant. Environ. Sci. Technol. 1995, 29, 903-913.

42. Chappell, M.A.; Laird, D.A.; Thompson, M.L.; Evangelou, V.P. Cosorption of atrazine and a lauryl polyoxyethylene oxide nonionic surfactant on smectite. J. Agric. Food Chem. 2005, 53, 10127-10133.

43. Zhang, M.; He, F.; Zhao, D.; Hao, X. Degradation of soil-sorbed trichloroethylene by stabilizedzero valent iron nanoparticles: Effects of sorption, surfactants, and natural organic matter. Water Res. 2011, 45, 2401-2414.

44. Liu, Z.; Edwards, D.; Luthy, R. Sorption of non-ionic surfactants onto soils. Water Res. 1992, 26, 1337-1345.

45. Mata-Sandoval, J.C.; Karns, J.; Torrents, A. Effects of rhamnolipids produced by Pseudomonas aeruginosa UG2 on the solubilization of pesticides. Environ. Sci. Technol. 2000, 34, 4923-4930.

46. Wang, P.; Keller, A.A. Partitioning of hydrophobic organic compounds within soil-water-surfactant systems. Water Res. 2008, 42, 2093-2101.

47. Gennari, M.; Messina, C.; Abbate, C.; Baglieri, A.; Boursier, C. Solubility and adsorption behaviors of chlorpyriphos-methyl in the presence of surfactants. J. Environ. Sci. Health. Part B 2009, 44, 235-240.

48. Southwick, L.M.; Willis, G.H.; Johnson, D.C.; Selim, H.M. Leaching of nitrate, atrazine and metribuzin from sugarcane in southern Louisiana. J. Environ. Qual. 1995, 24, 684-690.

49. Comfort, S.D.; Shea, P.J.; Roeth, F.W. Understanding Pesticides and Water Quality in Nebraska; Nebraska Cooperative Extension EC, University of Nebraska-Lincoln: Nebraska, USA, 1994.

50. Weber, J.B.; Keller, K.E. Mobility of Pesticides in Field Lysimeters. In Mechanisms of Pesticide Movement into Ground Water; Honeycutt, R.C., Schabacker, D.J., Eds.; Lewis Publishers: Boca Raton, FL, USA, 1994; pp. 43-62.

51. Bedmar, F.; Costa, J.L.; Suero, E.; Gimenez, D. Transport of atrazine and metribuzin in three soils of the humid pampas of Argentina. Weed Technol. 2004, 18, 1-8. 
52. Fan, M. Fate and Transport of Herbicides in a Sandy Soil in the Presence of Antibiotics in Poultry Manure. Master's Thesis, McGill University, Montreal, Canada, August 2009.

53. Pandiselvi, V.; Sathiyanarayanan, S.; Ayyappan, S.; Ramesh, A. Photolysis of metribuzin in water under direct sunlight - Identification of phototransformation products by LC-MS-MS electrospray tandem mass spectrometry and impact on aquatic species (Pseudokirchneriella subcapitata). Int. J. Res. Chem. Environ. 2012, 2, 251-262.

54. Sabadie, J. Degradation of bensulfuron-methyl on various minerals and humic acids. Weed Res. 1997, 37, 411-418.

55. Jurado-Exposito, M.; Walker, A. Degradation of isoproturon, propyzamide and alachlor in soil with constant and variable incubation conditions. Weed Res. 1998, 38, 309-318.

56. Kjaer, J.; Olsen, P.; Henriksen, T.; Ullum, M. Leaching of metribuzin metabolites and the associated contamination of a sandy danish aquifer. Environ. Sci. Technol. 2005, 39, 8374-8381.

57. Soares, A.; Guieysse, B.; Jefferson, B.; Cartmell, E.; Lester, J.N. Nonylphenol in the environment: A critical review on occurrence, fate, toxicity and treatment in wastewaters. Environ. Int. 2008, 34, 1033-1049.

58. Laha, S.; Luthy, R.G. Effects of nonionic surfactants on the solubilization and mineralization of phenanthrene in soil-water systems. Biotechnol. Bioeng. 1992, 40, 1367-1380.

59. Guha, S.; Jaffe, P.R. Bioavailability of hydrophobic compounds partitioned into the micellar phase of nonionic surfactants. Environ. Sci. Technol. 1996, 30, 1382-1391.

60. Allen, C.C.R.; Boyd, D.R.; Hempenstall, F.; Larkin, M.J.; Sharm, N.D. Contrasting effects of a nonionic surfactant on the biotransformation of polycyclic aromatic hydrocarbons to cis-dihydrodiols by soil bacteria. Appl. Environ. Microbiol. 1999, 65, 1335-1339.

61. Savage, K.E. Adsorption and mobility of metribuzin in soil. Weed Sci. 1976, 24, 525-528.

62. Bouchard, D.C.; Lavy, T.L.; Marx, D.B. Fate of metribuzin, metolachlor, and fluometuron in soil. Weed Sci. 1982, 30, 629-632.

63. Fuscaldo, F.; Bedmar, F.; Monterubbianse, G. Perseistance of atrazin, metribuzin and simazine herbicides in soils. Pesqui. Agropecu. Bras. 1999, 34, 2037-2044.

64. Selim, H.M. Retention and runoff losses of atrazine and metribuzin in soil. J. Environ. Qual. 2003, 32, 1058-1071.

65. Henriksen, T.; Svensmark, B.; Juhler, R.K. Degradation and sorption of metribuzin and primary metabolites in a sandy soil. J. Environ. Qual. 2004, 33, 619-627.

66. Villaverde, J.; Kah, M.; Brown, C.D. Adsorption and degradation of four acidic pesticides in soils from southern Spain. Pest Manag. Sci. 2008, 64, 703-710.

67. Maqueda, C.; Villaverde, J.; Sopena, F.; Undabeytia, T.; Morillo, E. Effects of soil characteristics on metribuzin dissipation using clay-gel-based formulations. J. Agric. Food Chem. 2009, 57, 3273-3278.

68. Bowman, B.T. Mobility and dissipation studies of metribuzin, atrazine and their metabolities in plainfield sand using field lysimeters. Environ. Toxicol. Chem. 1991, 10, 573-579.

69. Di, H.J.; Aylmore, L.A.G.; Kookana, R.S. Degradation rates of eight pesticides in surface and subsurface soils under laboratory and field conditions. Soil Sci. 1998, 163, 404-411.

70. Denial, P.E.; Bedmar, F.; Costa, L.J.; Aparicio, V.C. Atrazine and metribuzin sorption in soils of the Argentinean humid pampas. Environ. Toxicol. Chem. 2002, 21, 2567-2572. 
71. Jebellie, J.; Prasher, S.O. Role of water table management in reducing metribuzin pollution. Trans. ASAE 1998, 41, 1051-1060.

72. Olness, A.; Basta, N.T.; Rinke, J. Redox effects on resin extraction of herbicides from soil. Talanta 2002, 57, 383-391.

73. Muller, K.; Magesan, G.N.; Bolan, N.S. A critical review of the influence of effluent irrigation on the fate of pesticides in soil. Agric. Ecosyst. Environ. 2007, 120, 93-116.

74. Xiarchos, I.; Doulia, D. Effect of nonionic surfactants on the solubilization of alachlor. J. Hazard. Mater 2006, B136, 882-888.

75. Jafverti, C.T.; Vanhoof, P.L.; Heath, J. Solubilization of non polar compounds by non ionic surfactant micelles. Water Res. 1994, 28, 1009-1017.

76. Aggarwal, V.; Li, H.; Laird, D.A.; Boyd, S.A.; Johnston, C.T.; Teppen, B.J. Sorption of Triazines and Trichloroethene to Homoionic Smectites. In Proceedings of the 18th World Congress of Soil Science, Philadelphia, PA, USA, 9-15 July 2006.

77. Health Canada, 2010. Available online: http://www.hc-sc.gc.ca/ewh-semt/pubs/water-eau/2010sum_guide-res_recom/index-eng.php (accessed on 24 August 2011).

78. Cheah, P.S.; Reible, D.; Valsaraj, K.T.; Constant, D.; Walsh, W.; Thibodeaux, L.J. Simulation of soil washing with surfactants. J. Hazard. Mater. 1998, 59, 107-122.

79. Zimmerman, J.B.; Kibbey, T.C.G.; Cowell, M.A.; Hayes, K.F. Partitioning of ethoxylated nonionic surfactants into nonaqueous-phase organic liquids: Influence on solubilization behavior. Environ. Sci. Technol. 1999, 33, 169-176.

80. Kile, D.E.; Chiou, C.T. Water solubility enhancement of DDT and Trichlorobenzene by some surfactants below and above the critical micelle concentration. Environ. Sci. Technol. 1989, 23, 832-838.

81. Laird, D.A.; Koskinen, W.C. Triazine Soil Interactions. In The Triazine Herbicides, 50 years Revolutionizing Agriculture; Lebaron, H.M., Macfarland, J.E., Burnside, O.C., Eds.; Elsevier: San Deigo, CA, USA, 2008; pp. 275-299.

82. Undabeytia, T.; Recio, E.; Maqueda, C.; Morillo, E.; Gomez-Pantoja, E.; Sanchez-Verdejo, T. Reduced metribuzin pollution with phosphatidylcholine-clay formulations. Pest Manag. Sci. 2011, 67, 271-278.

(C) 2013 by the authors; licensee MDPI, Basel, Switzerland. This article is an open access article distributed under the terms and conditions of the Creative Commons Attribution license (http://creativecommons.org/licenses/by/3.0/). 